lished data ${ }^{3}$, partly on evidence which has come to light since.) For the purpose of describing the orientation of this platelet in the unit cell, the short and the long axes of the ellipse will be termed $A$ and $B$, and an axis at right angles to the other two will be termed $C$. In methæmoglobin, $A$ and $B$ are known to lie parallel to the $x$ and $y$ axes respectively. The close correspondence between the two vector maps (Fig. 3)

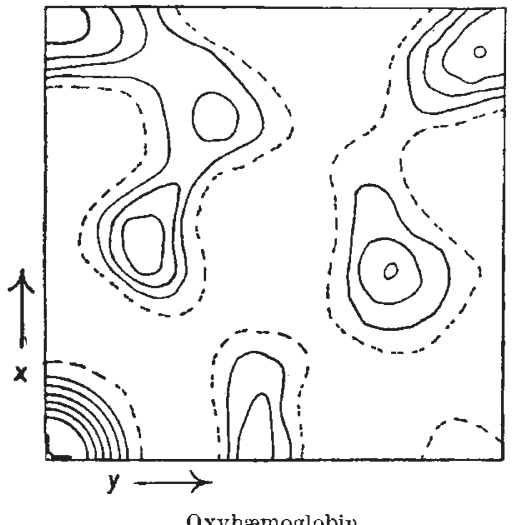

Oxyhæmoglobin

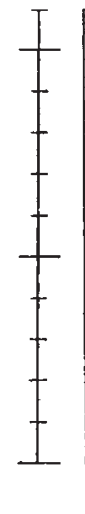

Fig. 2

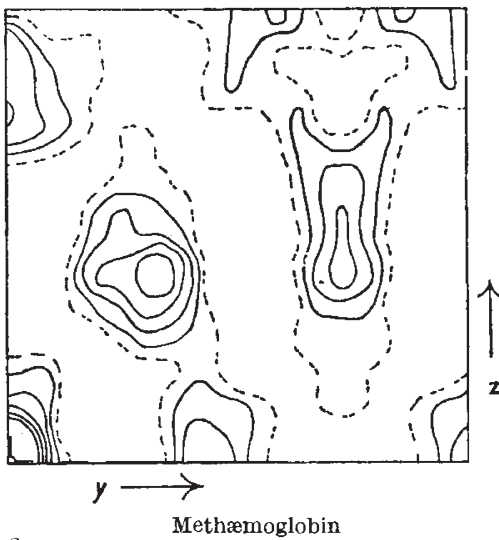

Methæmoglobin
COMPARISON OF THE $c$ PROJECTION OF OXYHFMOGLOBIN WITH THE $a$ PROJECTION OF METH Only the central portions of the projections are shown. The Fouricr summation for methæmoglobin was carried out by Dr. D. P. Riley, of Oxford.

indicates that in oxyhæmoglobin $B$ is parallel to $y$ and $C$ encloses an acute angle with $x$. The exact angle cannot be determined from the maps, because they merely show projections of the peaks the heights of which above the plane of projection are unknown. If the angle $C-x$ is, say, $30^{\circ}$, then the symmetry elements of the space group would require the angle to be $+30^{\circ}$ for one pair of molecules in the unit cell and $-30^{\circ}$ for the other. Such an arrangement would

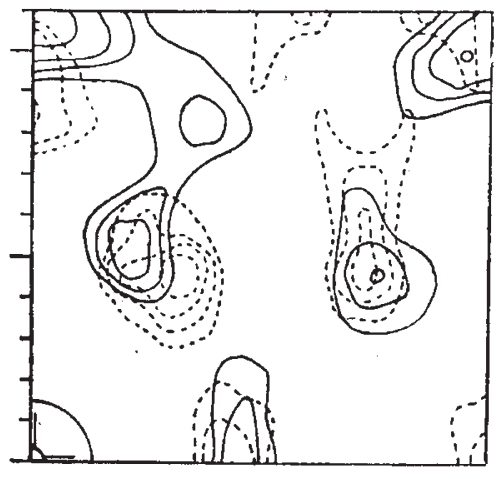

Fig. 3.

SUPFRPOSITION OF THF TWO PROJECTIONS SHOWN IN FIG. 2

The zero contours are now omitted: the full lines refer to oxyhmoglobin and the dashed ones to methæmoglobin. In both Figs, 2 and 3 the scales mark intervals of $2 \mathrm{~A}$.

account for the optical properties in a qualitative way : while in methæmoglobin the molecules all lie in line and the high birefringence and dichroism of the crystals give a true picture of the optical anisotropies of the individual hæmoglobin molecule, in oxyhæmoglobin the directions of maximum and minimum birefringence and optical absorption in the two pairs of molecules would be opposed in such a way as to compensate each other. The reversion of the sign of the birefringence on drying could be brought about by a slight change in the tilt of the molecule, namely, the angle $C-x$.

The vector maps of oxyhæmoglobin are simpler in some respects than those of other proteins. Some, at least, of the peaks can be traced unambiguously in all three projections and co-ordinates assigned to them; they are marked $L$, $M, N$, etc., in Fig. 1. It is disappointing though that the maps do not provide any clues to the relative positions of the molecules in the cell. Knowledge of the threedimensional vector structure might provide more evidence on this point. In the meantime, a structural model has been built up purely from considerations of packing, but further information is needed before it can beproved whether it is correct or not.

It is interesting to note that in dried crystals of oxyhæmoglobin, insulin ${ }^{5}$ and chymotrypsin' ${ }^{2}$, reflexions are observed at spacings so low as 7 A., while in dried methæmoglobin ${ }^{2}$ and lactoglobulin ${ }^{6}$ that limit is $13 \mathrm{~A}$. and $20 \mathrm{~A}$. respectively. The degree of shrinkage on drying in the first group lies between 20 per cent and 30 per cent, whereas in the second it reaches 50 per cent. This shows clearly how the degree of perfection of the crystal depends on the violence of the shrinking process.

I wish to thank Dr. E. F. Hartree for providing me with the crystals, Dr. D. P. Riley for carrying out one of the Fourier summations, and Miss M. J. BoyesWatson for preparing the drawings. I am greatly indebted to the Rockefeller Foundation for financing this research.

1 Bernal, J. D., Fankuchen, I., and Perutz, M. F., NAture, 141 , 523 (1938).

${ }_{2}^{2}$ Perutz, M. F., Nature, 143, 731 (1939).

s Perutz, M. F., Nature, 149, 491 (1942).

- Reichert, E. T., and Brown, A. P.."The Crystallography of the Hemoglobins"' (Washington, 1909)

${ }^{5}$ Crowfoot, D., Proc. Roy. Soc., A, 164, 580 (1938).

${ }^{6}$ Crowfoot, D., and Riley, D. P., NATURE, 141, 521 (1938).

\section{COUNCIL FOR SCIENTIFIC AND INDUSTRIAL RESEARCH, AUSTRALIA \\ ANNUAL REPORT}

7 HE fifteenth annual report of the Council for Scientific and Industrial Research, Commonwealth of Australia, covers the year ended June 30, 1941 , and includes the financial statoment as well as lists of publications of the Council and of the personnel of the Council and its committees and the committees concerning work in which the Council is co-operating.

A large part of the Council's activities is now devoted to the solution of problems arising out of the War, and to assistance and advice to various Government 
departments and other institutions and organizations which are concerned with that effort. This applies particularly to the National Standards Laboratory, the Aeronautical Research Laboratory, the Forest Products Laboratory and the Division of Industrial Chemistry. The reference to these activities is limited to brief general statements or omitted entirely.

Plant investigations have been concerned with native or naturalized plants as alternative sources of fibre, particularly as a substitute for jute, and investigations aimed at ascertaining the difference between the fibre from various Linum (flax) strains of good type are being continued. A survey is in progress to ascertain the position with regard to domestic sup. plies of vegetable and farm crop seed and methods of maintaining them. Weed investigations have shown that the St. John's wort can be virtually eliminated wherever subterranean clover can be grown successfully, but spraying with chemicals has failed to control an infestation of blackberry, and the work on both nutgrass (Cyperus rotundus) and mintweed (Salvia reflexa) has indicated that chemical sprays are of no value in controlling either plant. Field experiments on the control of take-all and the root-rot of wheat have continued at three sub-stations.

The work on the chemistry of tobacco at the University of Sydney was discontinued, as well as the study of disease resistance by the Section of Genetics. Work on the yellow dwarf disease, however, has continued actively, as well as investigations on smoking quality and physiological investigations. Fruit investigations have included an extension of the experiments on wax coatings for apples, and a reorganization to co-ordinate the wider attack on this problem organized by the Division of Food Preservation. A re-examination and summary of the results of the work carried out in Tasmania on the brownheart problem during the last five years has been made. Extended co-operation with the Tasmanian Department of Agriculture in experiments, particularly in relation to the effect of different stocks and pruning technique on the keeping quality of apples, has also been a feature of the season.

Other investigations have been concerned with storage disorders and with fruit physiology in relation to keeping quality and seasonal climate. Work on pre-storage treatments to increase the cool- and common-storage capacity has now been greatly expanded. A survey is also in progress in coastal Queensland areas to locate indigenous or naturalized plants, which may be sources of certain drugs such as caffeine, ephedrine, cocaine, quinine substitutes and substances such as derris. Attention has also been given to potato virus diseases, particularly to virus $X$, and trials have been made on fungicidal dusts for the treatment of maize seed. The dusts had no perceptible effect on germination or vigour of early growth, except at Canberra, and then only when inferior or diseased seed was used.

Laboratory work of the Division of Economic Entomology on weevil control has been concentrated chiefly on a study of mineral dusts, and gratifying results have been obtained with one or two effective non-silicious dusts readily available in Australia. Milling tests with treated wheat indicated that the dust is removed in the ordinary mill treating process, although the dust treatment has certain disadvantages such as its effect on the appearance and free running properties of the grain. Although the Division does not possess the special equipment required for accurate assessment of the relative toxicity of fumigants, a series of experiments with simple apparatus has been carried out to determine the susceptibility to fumigants of Calandra and Rhizopertha dominica to such fumigants as di- $\beta$-chloroethyl ether, chloropicrin, ethyl formate, o-dichlorobenzene, carbon disulphide, ethylene dichloride and carbon tetrachloride. Results indicate that Rhizopertha is more susceptible to all these fumigants than either of the Calandra species. Practical fumigation tests of infested wheat in concrete silos have been carried out with ethyl bromide and with Cyanogas G, the latter appearing to give almost complete control of Rhizopertha dominica. The sterilization of stack sites and sheds with petroleum oil and tar oil emulsions indicates that only those emulsions containing o-dichlorobenzene

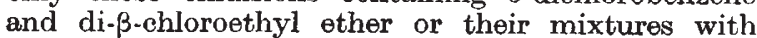
creosote and oil have given consistently good results for killing the developmental stages of $C$. granaria, $C$. oryzce and $R$. dominica, and good results have been obtained with emulsions of carbon disulphide or $o$-dichlorobenzene with crude naphthalene in the treatment of wheat shed floors when these are of loose earth in which infested grain may be buried.

In investigations on sheep blowfly, considerable progress has been made in compounding two useful dressings, the study of repellents and in an investigation of the breeding-ground of Lucilia cuprina, which is responsible for 90 per cent or more of strikes in Canberra. Toxicity studies using the contact toxicity technique indicate that 0.4 per cent of arsenious oxide is completely non-toxic to prepupæe when immersed for 30 minutes at $23^{\circ} \mathrm{C}$., and $\alpha \alpha$-dipyrridyl is almost as high in toxicity as nicotine, dinitro-ocyclohexyl-phenol and proflavine being only slightly toxic. Other entomological investigations have been concerned with the eradication of cattle ticks, insecticides for the control of wheat weevil and on the oriental peach moth. Animal health and nutrition investigations have covered pleuro-pneumonia of cattle, mastitis in dairy cattle, studies on phenothiazine as an anthelmintic, and blowfly problems and coast disease of sheep.

The Division of Forest Products Investigation has extended its work in the field of defence including the examination of numerous specifications for all kinds of defence and munition needs, the submission of advice on substitutes when necessary, and recommendations in regard to modified manufacturing methods or procedures ; its work is claimed to have resulted in savings in imports, in the amount of timber used and in the use of timber of lower quality. Flax investigations have been enlarged and both chemical and engineering research in this field are now centred in the Division. The promising work on chemical retting is being revived and problems of scutching, tow treatment, drying of retted straw and control of dew retting are also being studied.

Food preservation investigations have covered problems in the preparation and transport of boneless frozen meat, chiefly for the use of fighting services overseas, canning problems, the use of o-phenyl-phenol in fillers to restrict bacterial waste in stored eggs, the storage of whole egg powder, the handling, treatment and storage of fruit, etc., investigations which will in future be co-ordinated by a special committee representing all bodies carrying out work in this field. Protective skin coatings for fruit have been investigated, particularly the preparation of colloidal wax emulsions that leave clear bright films on drying. Chemical treatments for the control of mould wastage 
in stored grains have also been investigated. Fisheries investigations have covered smoking of fish, fish liver oil production, and investigations on Australian tunas, pilchards, mullets, etc.

Brief reference is made to the work of the National Standards Laboratory, to aeronautical investigations at the Aeronautical Laboratory, which has now been given the status of a Division, and to investigations in industrial chemistry, including that on unshrinkable wool, on wool wax, utilization of minerals and on producer gas investigations, particularly the suitability of Australian hardwoods for the production of charcoal. Substantial progress has been made in building up a research organization and the development of research methods for dealing with lubrication, bearing and wear problems in Australia. The work is undertaken as co-operative research with the University of Melbourne and housed in the new chemistry school. The work of the Dairy Research Section has included a survey of the properties of Australian butter and the storage and transport of butter fat without refrigeration.

\section{NORTH SYRIAN ARCHAOLOGY AND OLD TESTAMENT SOURCES}

$\mathrm{T}$

HE July-August number of Man contains, among other interesting matter, a résumé of the most recent results obtained by Commander Schaeffer at his Ras Shamra dig. North Syria was a very important area geographically in prehistoric times, and the excavations at Ras Shamra, like those of Mersin in Cilicia, alas scarcely more than begun, may well prove to be some of the most interesting in the Near East.

The early story of Ras Shamra goes back into Neolithic times, and a peculiar dark, incised pottery has been found in the lowest level, which, at Mersin, occurs in a definitely Neolithic milieu associated with a splendid industry made in obsidian. But at a later date Ras Shamra was a Bronze Age Canaanite town of considerable importance and the capital of the kingdom of Ugarit, well known in Egypt, Baby lonia and the Hittite empire. It was a meoting-place of Minoan, Mycenean, Babylonian and Anatolian cultures. Cuneiform texts have been unearthed which reveal the Canaanite mythology and were at any rate one of the sources drawn upon by the writers of the Old Testament.

he last $(1938-39)$ of the ten seasons of pre-war $k$ has considerably strengthened our knowledge his respect, having enabled certain documents to accurately dated; and it would now seem that ty of the Patriarchal stories of the Old Testament $\mathrm{H}_{\mathrm{g}}$ not mere oral tradition collected by authors of time of Solomon and later, but were part of a itten heritage derived from the Canaanite Bronze a. Furthermore, it would appear that some of 10 religious and moral progress achieved farther ?th. -y the great Old Testament prophets had already started some centuries earlier in the mothercivilization of that Israelite culture which has meant so much to the world.

The latest work also unearthed the royal palacefortress, which was protected by square towers of massive stone-work and in which were found the royal archives. The contents of the palace as a whole were very interesting and included a fine gold encrusted battle-axe with an iron blade belonging to the end of the fifteenth century B.C., as well as the muster roll of the army of Ugarit, naming the oificers and men and the number of bows and slings handed over to them. The tale of dismantling, restoration and final destruction which the excavations unfold seems to show that this kingdom of Ugarit with its capital of Ras Shamra finally went under at the beginning of the twelfth century B.C. to those same northern sea-borne invaders who effected the ruin of Troy. All this new information we owe to Ras Shamra and the latoours of Commander Schaeffer and his archæological and literary helpers.

M. C. Burkitt.

\section{FEEDING AND BREEDING OF CALANUS FINMARCHICUS}

$T$ HE importance of Calanus finmarchicus in the economics of the sea is so great that more attention has been paid to it than to any other copepod. That Dr. F. Gross and Mr. J. E. G. Raymont are now able to keep the adults for months under controlled conditions is a very definite advance on former work, and the two papers now before us are full of interest and suggestive observations ${ }^{1}$.

Dr. Gross ${ }^{2}$, in previous experiments, had made successful persistent cultures of many diatoms, using "Erdschreiber" as medium (a combination of nitrates, phosphates and soil extract) and had specialized in extending the method to minute flagellates. The present work on Calanus depends on its feeding on these cultures-both diatoms and flagellates-and its main importance lies in the fact that such food is found to be sufficient for the adults during their normal life-time. It is shown conclusively that for long periods Calanus can live entirely on a diatom diet, or one of diatoms and flagellates together, provided that there is a large amount of the food present, much more than under natural conditions in the sea. For a shorter period, they can live on flagellates alone. Nicholls ${ }^{3}$, from field data, placed the life of an adult female at about six weeks. In Raymont's and Gross's large cultures of females, more than half the animals generally remained healthy for three to nine weeks, while a few were kept active for more than a hundred days. The maximum number of adult animals which could live successfully in 200 c.c. Erdschreiber medium, with excess of food and weekly change of medium, was approximately twenty. Adult males did not live so long as the females, and this is probably what takes place in Nature, as has already been suggested by Ruud ${ }^{4}$. The present experiments show that the females feed more actively than the males, the number of freal pellets being more than 2-10 times as great and the size of the pellets of the females greatly exceeding those of the males. The moulting of Stage $\mathrm{V}$ was found to be a critical stage when many specimens died.

The diatoms used included large and small species, the large Ditylium being specially useful. That Calanus finmarchicus is a mixed feoder in its natural surroundings is well known, and it has been shown by Lebour ${ }^{5}$ and Marshall ${ }^{6}$ that Crustacea remains are sometimes to be found in the gut contents. Marshall states that "a certain proportion of Calanus are always found eating crustaceans" She found that 7-48 per cent of the guts examined contained Crustacea, according to the season, and they were usually taken 